\title{
PEDOTRANSFER FUNCTIONS FOR WATER RETENTION IN THE MAIN SOILS FROM THE BRAZILIAN COASTAL PLAINS
}

\author{
Funções de pedotransferência para retenção de água nos \\ principais solos dos tabuleiros costeiros brasileiros
}

\author{
Elidiane da Silva ${ }^{1}$, Nilton Curi², Mozart Martins Ferreira' ${ }^{2}$, Margarete Marin Lordelo Volpato ${ }^{3}$, \\ Walbert Júnior Reis dos Santos ${ }^{4}$, Sérgio Henrique Godinho Silva ${ }^{4}$
}

\begin{abstract}
Pedotransfer functions (PTFs) are equations used to estimate soil characteristics difficult to determine from other easily obtained ones. Water retention in soil is used in several agronomic and environmental applications, but its direct determination is time consuming and onerous, therefore PTFs are alternatives to obtaining this information more quickly and economically. The aims of this study were to generate a database and develop PTFs for water retention at potentials of $-33 \mathrm{kPa}$ (field capacity) and $-1500 \mathrm{kPa}$ (permanent wilting point) for Yellow Argisol and Yellow Latosol from the Brazilian Coastal Plains region. The Coastal Plains soils are mostly developed from Barreiras formation (pre-weathered sediments) and their main uses are sugarcane, livestock, forestry and fruticulture. The database to generate the PTFs was composed from the selection of information derived from scientific works and soil survey reports of the region. Specific PTFs were generated for each soil class, in their respective A and B horizons and for solum, through multiple regression by stepwise package of $\mathrm{R}$ language programming. Due to the small pedological variability (small number of soil classes containing great geographical expression) and mineralogical uniformity, usually observed in this environment, non-stratification of soil classes to create general PTFs presented similar or superior results compared to equations for each soil class. The adjustment of data demonstrated that water retention values at $-33 \mathrm{kPa}$ and $-1500 \mathrm{kPa}$ potentials can be estimated with adequate accuracy for the main soils of the Brazilian Coastal Plains through PTFs mainly from particle size distribution and secondarily from organic matter data.
\end{abstract}

Index terms: Database; pedofunction; permanent wilting point; field capacity.

\section{RESUMO}

Funções de pedotransferência (FPTs) são equações usadas para estimar atributos de solo de difícil determinação, a partir de outras mais facilmente obtidas. A retenção de água no solo é utilizada em diversas aplicações agronômicas e ambientais, porém sua determinação direta é demorada e onerosa. Com isso, as FPTs são alternativas para obtenção dessas informações de forma mais rápida e econômica. Conduziu-se este trabalho, com os objetivos de gerar um banco de dados e desenvolver FPTs para a retenção de água nos potenciais de $-33 \mathrm{kPa}$ (capacidade de campo) e -1500 kPa (ponto de murcha permanente) para Argissolo Amarelo e Latossolo Amarelo, da região dos Tabuleiros Costeiros brasileiros. Os solos dos Tabuleiros Costeiros são, principalmente, provenientes de sedimentos pré-intemperizados da Formação Barreiras e seus principais usos são cana-de-açúcar, pecuária, silvicultura e fruticultura. O banco de dados para geração das FPTs foi composto, a partir da seleção de informações obtidas de trabalhos científicos e de relatórios de levantamentos de solos da região. Foram geradas FPTs específicas para cada classe de solo em seus respectivos horizontes A e B e para o solum, e FPTs gerais, englobando as classes de solos e seus horizontes, por meio de regressão múltipla, através do pacote stepwise da linguagem de programação R. Em razão da pequena variabilidade pedológica (pequeno número de classes de solos com grande expressão geográfica) e alta uniformidade mineralógica, comumente observadas neste ambiente, a não estratificação das classes de solos para a criação de FPTs gerais demonstrou resultados similares ou superiores em relação às equações específicas para cada classe de solo. O ajuste dos dados demonstrou que os valores de retenção de água nos potenciais de $-33 \mathrm{kPa}$ e $-1500 \mathrm{kPa}$ podem ser estimados com adequada acurácia para os principais solos dos Tabuleiros Costeiros brasileiros, por meio de FPTs, a partir de dados de textura, principalmente, e matéria orgânica, secundariamente.

Termos para indexação: Banco de dados; pedofunções; ponto de murcha permanente; capacidade de campo.

\section{INTRODUCTION}

The importance of knowledge about hydrical characteristics of soil is related to its direct influence on water reservoir and availability to plants. These characteristics are difficult to be determined due to the high cost analyses, time and personal demand. In order to facilitate the obtaining of data on water content at specific matric potentials, many researchers have proposed mathematical models for estimating water retention from

\footnotetext{
1Universidade Federal de Lavras/UFLA - Departamento de Ciências do Solo/DCS - Cx. P. 3037 - $37200-000$ - Lavras - MG - Brasil elidianeagroufla@gmail.com

${ }^{2}$ Universidade Federal de Lavras/UFLA - Departamento de Ciências do Solo/DCS - Lavras - MG - Brasi

${ }^{3}$ Empresa de Pesquisa Agropecuária de Minas Gerais/EPAMIG - Lavras - MG - Brasil

${ }^{4}$ Instituto Federal de Educação, Ciência e Tecnologia do Sul de Minas Gerais - Muzambinho - MG - Brasil

Received in november 11, 2014 and approved in january 20, 2015
}

Ciênc. Agrotec., Lavras, v. 39, n. 4, p. 331-338, jul./ago., 2015 
easily obtained and fast determination attributes. These models are denominated Pedotransfer Functions (PTFs). In Brazil, the major difficulty to the development of such models is the relative scarcity of data bases in different regions.

The PTFs are commonly utilized in Soil Science, Hydrology and Agrometeorology for estimating water conductivity, water retention curve and parameters related to soil water infiltration (Medeiros et al, 2014). Many models utilize PTFs for simulating soil water, air and solutes transport, compaction, structure stability, and penetration resistance (Botula et al., 2014).

For different soils of Rio Grande do Sul State, Santos et al. (2013) verified that data of water retention at -33 and $-1500 \mathrm{kPa}$ matric potentials can be estimated from particle size distribution and organic matter data and the stratification by soil classes increases the PTF accuracy due to the great pedological and mineralogical variability.

The Brazilian Coastal Plains environment represents a 20 million hectares area (Souza, 2010, personal information). The soils are mainly derived from pre-weathered sediments of Barreiras Formation and the more expressive uses are sugarcane, cattle raising, forestry (eucalyptus) and fruticulture (Fonsêca et al., 2007). A remarkable characteristic of those soils are the cohesive subsuperficial horizons, which difficult the root system deepening and maximize the water stress mainly for perennial crops (Carvalho Filho; Curi; Fonseca, 2013). The subsoiling practice at greater depths has been applied to minimize such constraints. According to Curi and Ker (2004) and Carvalho Filho, Curi and Fonseca (2013), the main soil classes are Yellow Argisols (Ultisols), followed by Yellow Latosols (Oxisols).

The objectives of this study were to generate a soil database from the selection of soil profiles data of scientific works and soil survey reports from the Brazilian Coastal Plains region and to develop PTFs for estimating the water retention for the main soils of this environment, taking into account particle size distribution and organic matter as independent variables, keeping in mind the known interdependence among these characteristics.

\section{MATERIAL AND METHODS}

The database for PTFs generation was composed of soil profiles data from scientific works and soil survey reports of the Brazilian Coastal Plains region. 69 soil profiles were utilized, being 55 of Yellow Argisol (YA) and 14 of Yellow Latosol (YL), making up a total of 138 soil horizons (A and $\mathrm{B}$ ). In Table 1, it is presented the bibliographical source, the number of soil profiles and horizons utilized in this study.

It were selected scientific works that employed disturbed samples, considering that, in the vast majority of soil surveys, soil water retention is measured using disturbed samples, and that the collecting of undisturbed samples is more time-consuming and more expensive, besides the fact that the disturbed samples present lower variability in such measurements. It is known that in higher matric potentials such as $-33 \mathrm{kPa}$ (Field Capacity - FC), the water retention is influenced by structure (Oliveira et al., 2002) and the FC is overestimated for most soils, except for sandy soils (Bell; Van Keulen, 1995). However, this methodology is justified considering two main reasons: the development of these PTFs seeks maximum efficiency with simple and low cost input data, and most of the potential users of these PTFs are in countries with low amount of data, case of Brazil and other tropical countries. In addition, papers such as Oliveira et al. (2002) and Santos et al. (2013) obtained adequate PTF fitting utilizing disturbed soil samples.

The database was stratified by soil class (YA and YL), soil horizon (A and B) and solum. The data were submitted to multiple regression in $\mathrm{R}$ programming language, using the stepwise package. The independent variables for generating the PTFs were particle size distribution, organic matter and water content at -33 $\mathrm{kPa}$ and $-1500 \mathrm{kPa}$, corresponding to field capacity and permanent wilting point.

Table 1: Bibliogaphical source, number of soil profiles and horizons used for elaborating the PTFs.

\begin{tabular}{ccc}
\hline Source & Number of soil profiles & Number of soil horizons \\
\hline Santos (2014) & 22 & 44 \\
Araújo Filho et al. (1999) & 16 & 32 \\
Curi and Ker (2004) & 23 & 46 \\
Nunes (Personal Information) & 8 & 16 \\
\hline Total & 69 & 138 \\
\hline
\end{tabular}

Ciênc. Agrotec., Lavras, v. 39, n. 4, p. 331-338, jul./ago., 2015 
In addition, PTFs were generated without soil classes and horizons stratification in order to test the need of data separation.

The PTFs performance was evaluated by means of the following statistical parameters: determination coefficient $\left(\mathrm{R}^{2}\right)$, estimative standard error (ESE) and 1:1 relation of estimated versus observed data.

The $\mathrm{R}^{2}$ measures how well the model can explain the observed values. The ESE measures the average deviation between the Y real and estimated values. It provides approximate information on the error extension between the estimated values and the values obtained by PTF functions.

\section{RESULTS AND DISCUSSION}

Table 2 presents the minimum, maximum and average values of samples from the database utilized for generating PTFs, in which can be observed a great data range.

The organic matter ranged from 0.1 to $8.5 \mathrm{dag}$ $\mathrm{kg}^{-1}$. Clay, silt, fine sand and coarse sand ranged from 3

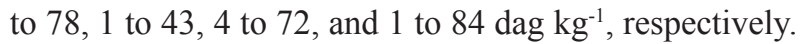
The water content retained at $-33 \mathrm{kPa}(\mathrm{FC})$ and $-1500 \mathrm{kPa}$ (PWP) varied from 2.6 to 25.8 , and from 0.9 to 18.4 dag $\mathrm{kg}^{-1}$, respectively.

Table 3 presents the PTFs for Yellow Argisol (YA), Yellow Latosol (YL) and for both soils (General) considering $\mathrm{A}$ and $\mathrm{B}$ horizons separately and together (solum), for water content at $-33 \mathrm{kPa}$ and -1500 $\mathrm{kPa}$, with their respective $\mathrm{R}^{2}$ and ESE. The multiple regression equations presented significative $\mathrm{R}^{2}$ at $5 \%$ probability. For $-33 \mathrm{kPa}$ potential, $\mathrm{R}^{2}$ values ranged from 0.32 to 0.73 . For $-1500 \mathrm{kPa}$, these values ranged from 0.12 to 0.75 .
The highest $\mathrm{R}^{2}$ values occurred when there was not an A and B horizons stratification (solum), being this behavior applied for individual soils as well as for the general model for both soil classes. This fact can be explained by the great mineralogical uniformity in the soils (Duarte et al., 2000; Resende et al., 2011; Carvalho Filho; Curi; Fonseca, 2013) and in the parent material of soils from this environment (Nascimento et al., 2010). The lower $\mathrm{R}^{2}$ values for $\mathrm{YL}$ can be related to this soil class being in much smaller number in the database, in agreement with its much smaller geographical expression in the Brazilian Coastal Plains (Carvalho Filho, Curi; Fonsêca, 2013).

The general PTF presented $\mathrm{R}^{2}$ very close or superior to that involving data stratification by soil classes due to the smaller pedological variability (small number of soil classes having great geographical expression) of this environment. The general PTFs with the junction of $\mathrm{A}$ and $\mathrm{B}$ horizons (solum) revealed high predictive power for the estimation of water content at $-33 \mathrm{kPa}$ and $-1500 \mathrm{kPa}, 73 \%$ and $75 \%$, respectively. The higher $\mathrm{R}^{2}$ values, followed by the lower ESE (Table 3), observed in the predictive equations of water content at $-1500 \mathrm{kPa}$ matric potential, are indicative of the better expressed relationships between water retention and particle size distribution at more elevated tensions, besides the presence of stable microaggregates, according to Oliveira et al. (2002).

Figures 1, 2 and 3 illustrate the correlation results between the observed and predicted data for the YA, YL and General models, respectively. In Table 3, the junction of soil classes presented high predictive power of equations, allowing a higher data entry for generation of PTFs.

Table 2: Minimum, maximum and average values of variables from the database utilized for generating PTFs.

\begin{tabular}{cccc}
\hline \multirow{2}{*}{ Variables $\left(\right.$ dag $\left.\mathrm{kg}^{-1}\right)$} & \multicolumn{3}{c}{ Values } \\
\cline { 2 - 4 } & Minimum & Maximum & Average \\
\hline SOM & 0.1 & 8.5 & 1.5 \\
Clay & 3 & 78 & 25.9 \\
Silt & 1 & 43 & 8.1 \\
Fine sand & 4 & 72 & 26.6 \\
Coarse sand & 1 & 84 & 45.4 \\
FC & 2.6 & 25.8 & 14.6 \\
PWP & 0.9 & 18.4 & 8.8 \\
\hline
\end{tabular}

SOM (Soil organic matter); FC (Field capacity (-33 kPa)); PWP (Permanent wilting point (-1500 kPa)). 
Table 3: Pedotransfer Functions (PTFs) for estimating the soil water retention at -33 and $-1500 \mathrm{kPa}$ matric potentials.

\begin{tabular}{|c|c|c|c|c|c|}
\hline & & Equations & $\mathrm{n}$ & $\mathrm{R}^{2}$ & ESE \\
\hline & & -------------------YA--------------------- & & & \\
\hline \multirow{2}{*}{ A horizon } & $\hat{\mathrm{U}}_{-33}$ & $5.495+0.2152$ clay $+0.8054 \mathrm{SOM}$ & 55 & 0.41 & 0.0311 \\
\hline & $\hat{\mathrm{U}}_{-1500}$ & $1.946+0.0037$ clay +0.2231 silt & 55 & 0.75 & 0.0351 \\
\hline \multirow{2}{*}{ B horizon } & $\hat{\mathrm{U}}_{-33}$ & $0.3071+0.2751$ clay +0.0938 silt & 55 & 0.63 & 0.0413 \\
\hline & $\hat{\mathrm{U}}_{-1500}$ & $2.2397+1.581$ clay & 55 & 0.67 & 0.0352 \\
\hline \multirow{3}{*}{ Solum } & $\hat{\mathrm{U}}_{-33}$ & $1.4443+0.2486$ clay $+0.5221 \mathrm{SOM}$ & 110 & 0.73 & 0.0418 \\
\hline & $\hat{\mathrm{U}}_{-1500}$ & $0.2583+0.084$ clay & 110 & 0.75 & 0.0466 \\
\hline & & --------------------YL---------------------' & & & \\
\hline \multirow{2}{*}{ A horizon } & $\hat{U}_{-33}$ & $1.854+0.2156$ clay $+0.8054 \mathrm{SOM}$ & 15 & 0.52 & 0.0442 \\
\hline & $\hat{\mathrm{U}}_{-1500}$ & $6.7168+0.2281$ clay & 15 & 0.62 & 0.0354 \\
\hline \multirow{2}{*}{ B horizon } & $\hat{\mathrm{U}}_{-33}$ & $0.3071+0.2751$ clay +0.0938 silt & 15 & 0.45 & 0.0347 \\
\hline & $\hat{\mathrm{U}}_{-1500}$ & $8.034+1.581$ clay & 15 & 0.55 & 0.0477 \\
\hline \multirow{3}{*}{ Solum } & $\hat{\mathrm{U}}_{-33}$ & $10.9435+0.5211$ silt -0.0995 clay & 30 & 0.64 & 0.0445 \\
\hline & $\hat{\mathrm{U}}_{-1500}$ & $5.4404+0.2246$ clay & 30 & 0.67 & 0.0367 \\
\hline & & ------------------General------------------- & & & \\
\hline \multirow{2}{*}{ A horizon } & $\hat{\mathrm{U}}_{-33}$ & $9.3274+0.058 \mathrm{SOM}+0.1014$ clay & 70 & 0.49 & 0.0465 \\
\hline & $\hat{\mathrm{U}}_{-1500}$ & $9.23+0.2511$ silt -0.074 fine sand & 70 & 0.58 & 0.0243 \\
\hline \multirow{2}{*}{ B horizon } & $\hat{\mathrm{U}}_{-33}$ & $9.7953-2.6231 \mathrm{SOM}+0.0891$ clay & 70 & 0.41 & 0.0364 \\
\hline & $\hat{\mathrm{U}}_{-1500}$ & $9.0821+0.3781$ clay & 70 & 0.52 & 0.0332 \\
\hline \multirow{2}{*}{ Solum } & $\hat{\mathrm{U}}_{-33}$ & $11.2394+0.0945$ clay & 140 & 0.73 & 0.0354 \\
\hline & $\hat{U}_{-1500}$ & $0.1781+0.2981$ clay & 140 & 0.75 & 0.0434 \\
\hline
\end{tabular}

$\hat{\mathrm{U}}_{-33}$ : moisture retained at $-33 \mathrm{kPa} ; \hat{\mathrm{U}}_{-1500}$ : moisture retained at $-1500 \mathrm{kPa}$; YA: Yellow Argisol; YL-Yellow Latosol; $\mathrm{R}^{2}$ : determination coefficient; ESE: estimative standard error.

The results found by Santos et al. (2013) for Rio Grande do Sul State soils demonstrated that for regions where the pedological and mineralogical variability is expressive (Streck et al. 2008), the stratification by soil classes for generating PTF results into higher coefficients than PTFs in which a small number of data of all soils is compiled in a sole model. Due to the smaller pedological and mineralogical variability in the Coastal Plains environment (Resende et al. 2011; Carvalho Filho; Curi; Fonseca, 2013), the junction of different soil classes (Yellow Argisol and Yellow Latosol) and soil horizons (A and B) did not cause a deleterious effect on coefficient of PTFs. It constitutes a recent support for future scientific and practical works. 

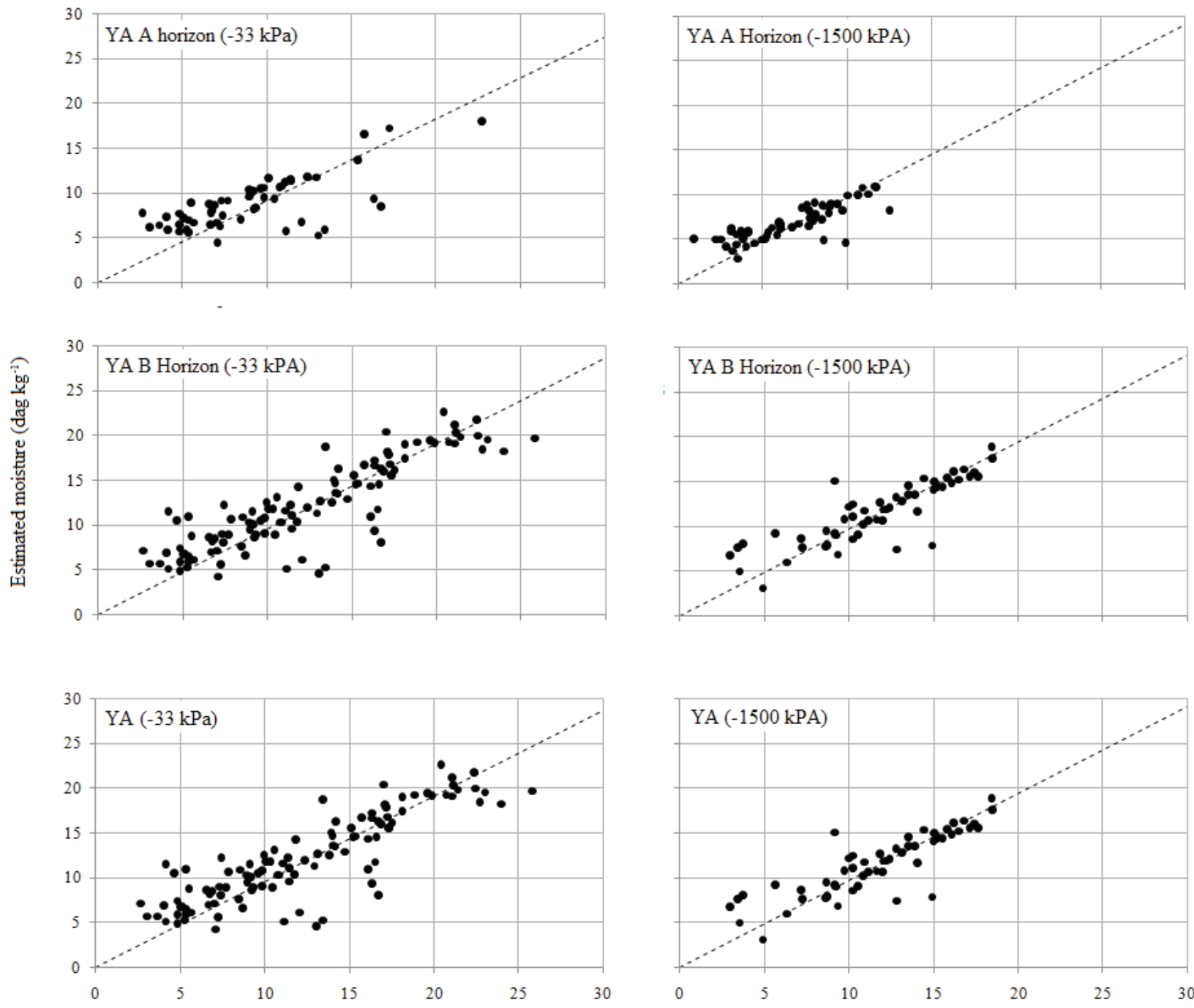

Observed moisture $\left(\right.$ dag kg $\left.^{-1}\right)$

Figure 1: 1:1 relation between observed and estimated values by the PTFs generated for the -33 and $-1500 \mathrm{kPa}$ matric potentials, for A and B horizons and for both of them (solum) in Yellow Argisol (YA). 

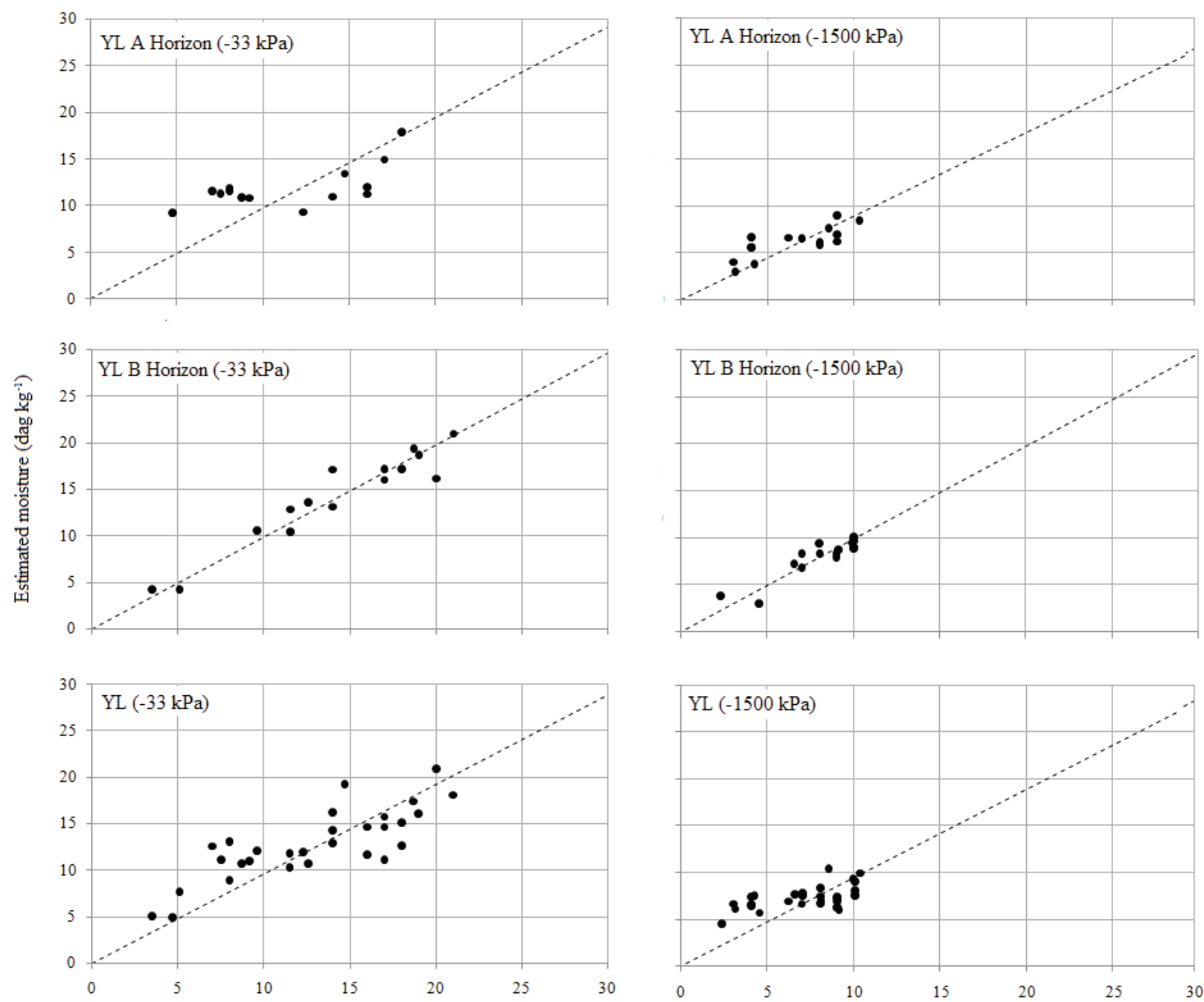

Observed moisture (dag $\mathrm{kg}^{-1}$ )

Figure 2: 1:1 relation between observed and estimated values by the PTFs generated for the -33 and $-1500 \mathrm{kPa}$ matric potentials, for A and B horizons and for both of them (solum) in Yellow Latosol (YL).

Ciênc. Agrotec., Lavras, v. 39, n. 4, p. 331-338, jul./ago., 2015 

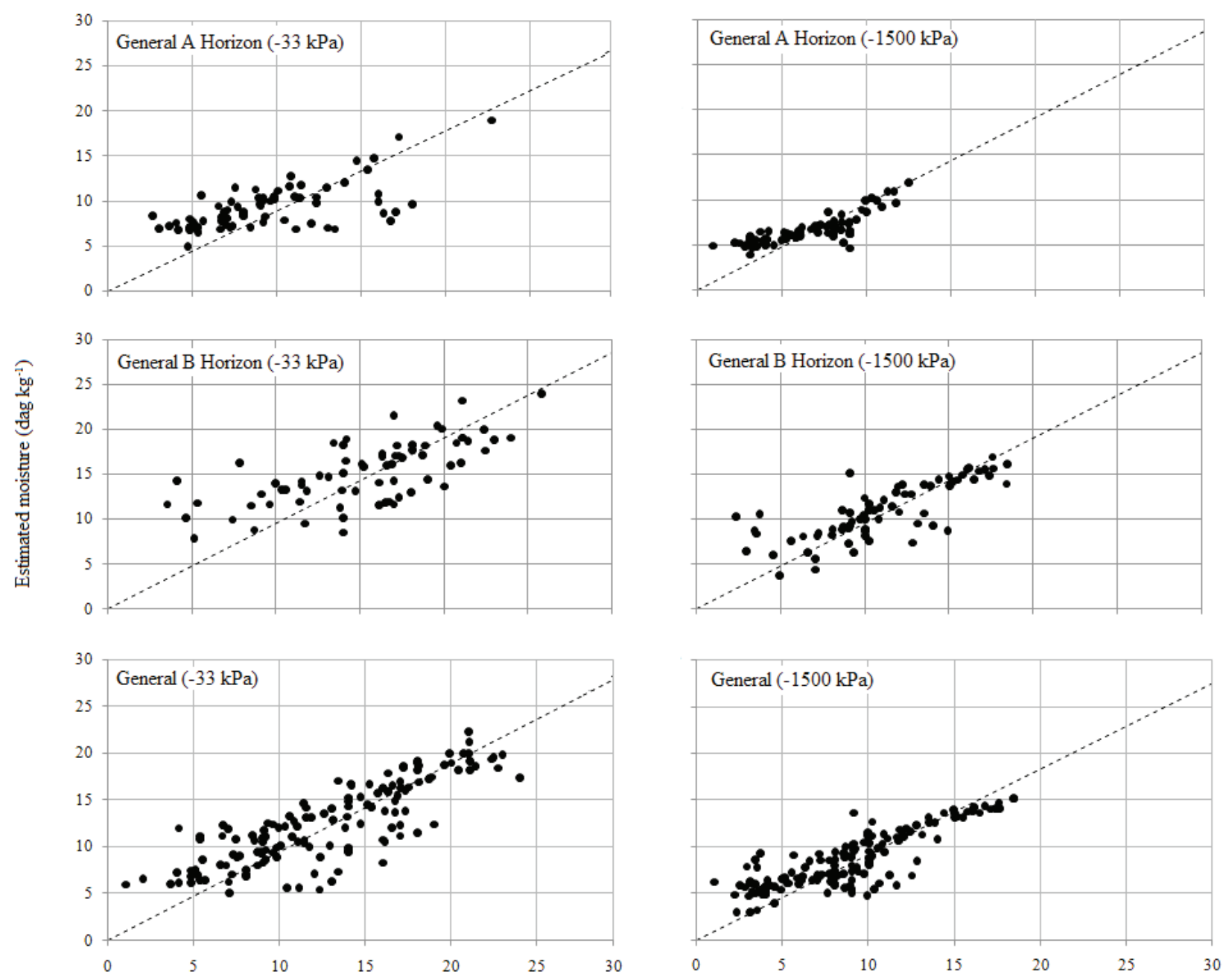

Observed moisture (dag kg-1)

Figure 3: 1:1 relation between observed and estimated values by the PTFs generated for the -33 and $-1500 \mathrm{kPa}$ matric potentials, for A and B horizons and for both of them (solum) in YA (Yellow Argisol) and YL (Yellow Latosol).

\section{CONCLUSIONS}

The water content retained at -33 and $-1500 \mathrm{kPa}$ in the main soils of the Brazilian Coastal Plains can be estimated, with adequate accuracy, from data of particle size distribution, mainly, and organic matter, secondarily.

Due to the small pedological and mineralogical variability in this environment, the non-stratification by soil classes and soil horizons for generating PTF produces similar or even superior results in comparison with specific equations, providing recent and valuable information for future scientific and practical works.
The equations with non-stratification by soil classes and horizons allow higher data entry for PTF generation, which increases their coefficients of determination.

\section{ACKNOWLEDGEMENTS}

To CNPq, CAPES and FAPEMIG for financial support. To Marta Vasconcelos Ottoni (CPRM), Luciano da Silva Souza (UFRB), Fábio Carvalho Nunes (IF Baiano) and José Coelho de Araújo Filho (EMBRAPA Solos), for database partial composition. 


\section{REFERENCES}

ARAÚJO FILHO, J. C. de et al. Levantamento de reconhecimento de média intensidade dos solos da região dos tabuleiros costeiros e da baixada litorânea do Estado de Sergipe. v. 2. Rio de Janeiro: Embrapa Solos, 1999. 388p.

BELL, M. A.; VAN KEULEN, H. Soil pedotransfer functions for four Mexican soils. Soil Science Society of America Journal. 59(3):865-871,1995.

BOTULA, Y.D. et al. Pedotransfer functions to predict water retention for soils of the humid tropics: A review. Revista Brasileira de Ciência do Solo. 38(3)679-698, 2014.

CARVALHO FILHO, A.; CURI, N.; FONSECA, S. Avaliação informatizada e validada da aptidão silvicultural das terras dos Tabuleiros Costeiros brasileiros para eucalipto. Lavras: Editora UFLA, 2013. 138p.

\section{CURI, N.; KER, J. C. Levantamento Pedológico} de áreas da nos estados da Bahia, Espírito Santo e Minas Gerais e sua interpretação para o cultivo de eucalipto e para o ambiente em geral. Aracruz: ARCEL, 2004. 1 CD ROM.

DUARTE, M. N. et al. Mineralogia, química e micromorfologia de solos de uma microbacia nos Tabuleiros Costeiros do Espírito Santo. Pesquisa Agropecuária Brasileira. 35(6):1237-1250, 2000.

FONSÊCA, M. H. P. et al. Uso de propriedades físicohídricas do solo na identificação de camadas adensadas nos Tabuleiros Costeiros, Sergipe. Revista Brasileira de Engenharia Agrícola e Ambiental. 11(4):368-373, 2007.

MEDEIROS, J. C. et al . Assessment of pedotransfer functions for estimating soil water retention curves for the amazon region. Revista Brasileira de Ciência do Solo. 38(3)730-743, 2014.

NASCIMENTO, G. D. et al. Funções de pedotransferência do conteúdo de água em Latossolos Amarelos e Argissolos Amarelos. Revista Brasileira de Ciências Agrárias. 5(4):560-569, 2010.

OLIVEIRA, L. B. et al. Funções de pedotransferência para predição da umidade retida a potenciais específicos em solos do Estado de Pernambuco. Revista Brasileira de Ciência do Solo. 26(2):315-323, 2002.

RESENDE, M. et al. Mineralogia de solos brasileiros: Interpretação e aplicações. 2. ed. Revisada e ampliada. Lavras: Editora UFLA, 2011. 206p.

SANTOS, W. J. R. et al. Pedotransfer functions for water retention in different soil classes from the center-southern Rio Grande do Sul State. Ciência e Agrotecnologia. 37(1):49-60, 2013.

SANTOS, W. J. R. et al. Detailed soil survey of an experimental watershed representative of the Brazilian Coastal Plains and its practical application. Ciência e Agrotecnologia. 38(1):50-60, 2014.

STRECK, E. V. et al. Solos do Rio Grande do Sul. 2. ed. Revisada e ampliada. Porto Alegre: EMATER/RS, 2008. 222 p. 